\title{
Antioxidant profile of Canada lettuce (Lactuca canadensis) and madeira vine (Anredera cordifolia) minimally processed
}

Vinícius Tadeu da Veiga Correia, Danielle Fátima D'Angelis, Luma Moura Brito, Jéssica Letícia Abreu Martins, Ernani Clarete da Silva, Lanamar de Almeida Carlos

Universidade Federal de São João Del-Rei - UFSJ, MG. E-mail: viniciustadeu18@hotmail.com

\begin{abstract}
This study aimed to evaluate the stability of natural antioxidants in minimally processed Anredera cordifolia and Lactuca canadensis and their physical-chemical and antioxidant characteristics at time zero of storage (TO) and after 3, 6, 9 and 12 days, at a temperature of $7{ }^{\circ} \mathrm{C}$. For the attribute color, L. canadensis did not show significant differences between the parameters, whereas $A$. cordifolia showed variation in its lightness from the third day of storage. Both vegetables had significant increments of $\mathrm{pH}$, which ranged from 5.77 to 6.16 in A. cordifolia and from 6.23 to 6.43 in L. canadensis. The contents of soluble solids also increased significantly, from 2.28 to $4.17^{\circ}$ Brix and from 4.89 to $6.30^{\circ}$ Brix in A. cordifolia and L. canadensis, respectively. No significant difference was observed in total titratable acidity at any of the times evaluated $(p>0.05)$. Among the bioactive compounds of the minimally processed vegetables, the contents of carotenoids, tannins, and total phenolic compounds were affected by storage, demonstrating that this process has an influence on the concentrations of the natural antioxidants studied.
\end{abstract}

Keywords: bioactive compounds; non-conventional food plants; nutritional quality.

Perfil antioxidante de almeirão-de-árvore (Lactuca canadensis) e bertalha (Anredera cordifolia) minimamente processados

\section{Resumo}

O objetivo deste trabalho foi avaliar a estabilidade de antioxidantes naturais em bertalha e almeirão-deárvore minimamente processados, bem como suas características físico-químicas, no ato do armazenamento (TO) e após 3, 6, 9 e 12 dias, na temperatura de $7{ }^{\circ} \mathrm{C}$. Em relação ao atributo cor, o almeirão não apresentou diferença significativa entre os parâmetros, já a bertalha, a partir do terceiro dia de armazenamento, demonstrou variação em sua luminosidade. As duas hortaliças apresentaram aumentos significativos de pH, variando de 5.77 a 6.16 para a bertalha e de 6.23 a 6.43 para o almeirão. Os teores de sólidos solúveis também aumentaram significativamente, 2.28 a $4.17^{\circ} \mathrm{Brix}$ e de 4.89 a $6.30^{\circ} \mathrm{Brix}$ para bertalha e almeirão, respectivamente. Já a acidez total titulável não apresentou diferença significativa para nenhum dos tempos avaliados ( $p>0.05$ ). Dentre os compostos bioativos das hortaliças minimamente processadas, os carotenoides, taninos e compostos fenólicos totais sofreram interferência do armazenamento sobre o seu conteúdo, demonstrando haver influência desse processo sobre as concentrações dos antioxidantes naturais estudados.

Palavras-chave: compostos bioativos; plantas alimentícias não convencionais; qualidade nutricional.

\section{Introduction}

Some of the species called non-conventional food plants are popularly known as nonconventional vegetables, weeds, and these nomenclatures are closely associated with the fact that these plants are not either cultivated, often occuring spontaneously in vegetable gardens, yards and orchards. In most cases, despite being widely spread, these plants are rarely used for consumption due to the low 
availability of information on their nutritional properties, market and forms of preparation (BRESSAN et al., 2011).

Vegetables are plants that contain in their structure relevant compounds from the nutritional and/or functional points of view, directly related to the prevention of some diseases (GRANATO et al., 2015; SAINI et al., 2016). Due to the high biodiversity in Brazil, it is possible to report a large variety of nonconventional vegetables which are low-cost and have nutritional importance (QUEIROZ et al., 2015), and Lactuca canadensis and Anredera cordifolia are examples of this food class.

With an estimated yield of 20 to $40 \mathrm{Kg} / \mathrm{ha}$, Canada lettuce (Lactuca canadensis) reaches lengths from 20 to $25 \mathrm{~cm}$ and exhibits variations of color in its leaf veins, which may be purple or greenish. Its taste is slightly bitter and its cultivation is predominantly carried out in areas with mild temperatures and nutrient-rich soils due to high contents of organic matter (EPAMIG, 2012).

Lactuca canadensis is a perennial herb with tuberous roots, which are usually dried and ground to be used as a tea, supplement or substitute for coffee. Besides, its leaves are consumed fresh, along with lettuce and chicory, in the preparation of leafy salads (MACHADO; BOSCOLO, 2018).

Native to the Indian subcontinent and Southeast Asia, Madeira vine (Anredera cordifolia) is a non-conventional herb with approximately $30 \mathrm{~cm}$ of length and heart-shaped dark-green leaves. This plant has numerous and whitish fragrant flowers, besides small, irregular aerial tubers (KINUPP; LORENZI, 2014).

Cultivated in hot climates, with temperatures between $26{ }^{\circ} \mathrm{C}$ and $28{ }^{\circ} \mathrm{C}$, and in nutrient-rich soils, Anredera cordifolia plants are usually found in vegetable gardens close to walls, where its development is often monitored, due to its growth habit. Its harvested when the leaves are smooth and tender, with a yield between 15 and 37 tons/ha (EPAMIG, 2012).

Usually used in foods, either stewed or in soups, like spinach, Anredera cordifolia is a source of several compounds, including saponins (TOSHIYUKI et al., 2001). Also, some amino acids such as arginine, leucine, isoleucine, threonine, and tryptophan, are also found in its composition. It is plant, that presents a climbing habit, and has no toxicity or mutagenic effect
(YEN et al., 2001), besides containing expressive contents of vitamins A and C (BRASIL, 2010).

The antioxidant potential of unconventional vegetables has stimulated studies through investigation of these compounds capable of neutralizing excessive free radicals that are formed, which are responsible for the development of non-communicable chronic diseases (NCDs), such as diabetes and certain types of cancer. Examples of antioxidant compounds and phenolic compounds, tannins and carotenoids, which are secondary metabolites produced by certain plants due to the adverse conditions of their growing environments, and when consumed can bring some benefits to people's health. Therefore, the content of these phytochemicals is directly influenced by factors such as genetics, environment, degree of maturity, variety of plants, storage condition, microorganisms deterioration, among others (NACZK; SHAHIDI, 2006; VIANA et al., 2015).

Thus, applying conservation technologies in unconventional vegetables may represent a possibility of retaining the loss of phytochemicals until the product reaches the consumer. And the minimal processing of vegetables is an alternative, since the characteristics of freshness, convenience and practicality of minimally processed foods have created a tendency to search for functional/healthy foods, innocuous and in smaller portions. Hence, a variety of products for immediate consumption has been offered on the market, saving time when preparing meals (RICO et al., 2007). Minimally processed foods are obtained by washing, sanitization, triage, peeling, cutting, packaging and storing, which constitute a set of physical operations that allow maintaining the state of freshness similar to the one found in fresh products (SANTOS et al., 2014).

All things considered it is essential to improve the knowledge of non-conventional food plant species with functional potential for consumers. Therefore, the objective of the present study is to evaluate the stability of natural antioxidants from non-conventional vegetables Lactuca canadensis and Anredera cordifolia to minimal processing and storage for 12 days at $7^{\circ} \mathrm{C}$. Analyze their physical-chemical characteristics as well.

\section{Material and Methods}

Leaves of Canada lettuce (Lactuca canadensis) and Madeira vine (Anredera cordifolia) were 
harvested at the germplasm bank of Nonconventional Vegetables of EPAMIG (Agriculture and Livestock Research Enterprise of Minas Gerais) - Santa Rita Farm, located in the city of Prudente de Morais - Minas Gerais state, Brazil

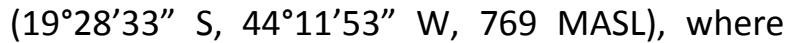
plants are grown with no use of pesticides. The samples were transported under refrigeration, where they were minimally processed and then subjected to analysis of physical-chemical parameters, phenolic compounds, carotenoids, and tannins. At harvest, an attempt was made to select showy leaves without any injury or contamination, either by insects and fungi, in a homogeneous stage of maturity (Figure 1). The rigid polyethylene packages (PET, SANPACK S-13 $\mathrm{C} / 200$ ) used to store the vegetables were purchased at a commercial establishment in the city of Sete Lagoas - MG.

Initially, the vegetables were washed in running water, sanitized for 5 minutes in sodium hypochlorite solution with $150 \mathrm{ppm}$ of active chlorine, and subsequently drained with the aid of a manual centrifuge to remove excess water. After drainage, the samples (approximately 100 g) were placed in transparent plastic packages and stored in a BOD incubator at $7{ }^{\circ} \mathrm{C}$ for 12 days.

At the zero time of storage (TO) and every three days, that is, after 3, 6, 9 and 12 days, samples were collected for physical-chemical evaluations and quantification of bioactive compounds.

Figure 1. Plants used in the experiment, harvested in the bank of non-conventional vegetables of EPAMIG, (A) - Lactuca canadensis and (B) - Anredera cordifolia. Source: the author, 2020.

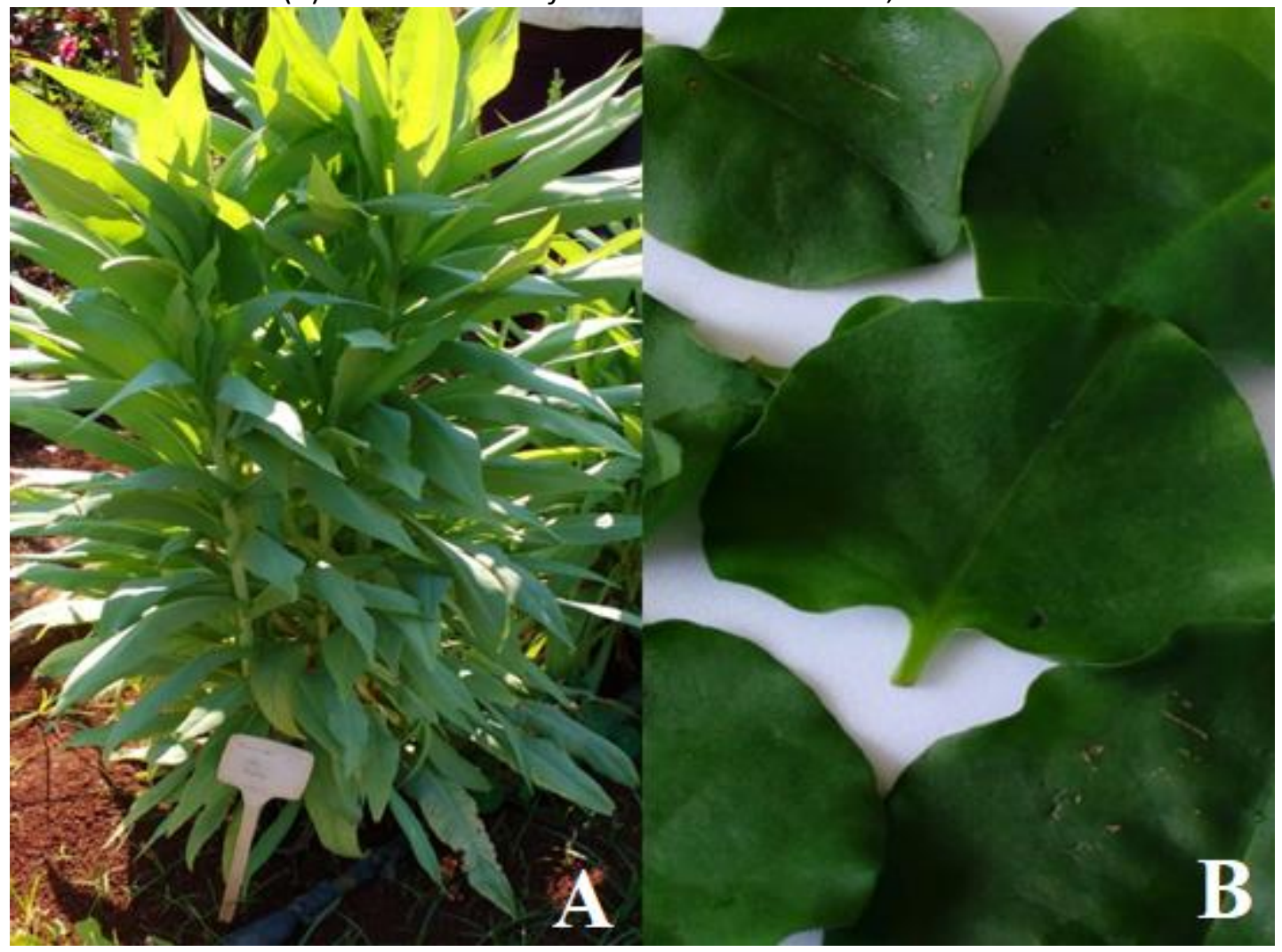

\section{Physical-chemical analyses}

The contents of total soluble solids (TSS) were determined by grinding, homogenizing and filtrating the leaves liquid portion. Drops of the filtrate with no solids in suspension were placed on the prism of a digital refractometer (REICHERT r2MINI), with results expressed in ${ }^{\circ} \mathrm{BRIX}$. Moisture content was determined by the gravimetric method in an oven at $105^{\circ} \mathrm{C}$, and the calculations were made based on the weights of the samples before and after water removal by heating (AOAC, 2012).

This attribute was determined by potentiometry, according to the methodology of AOAC (2012), in a digital pH meter (TEKNA, T1000). The electrode was immersed in the sample which had been ground and homogenized with $25 \mathrm{~mL}$ of distilled water. 
Total titratable acidity (TTA) was determined by titration, using a standard solution of $0.01 \mathrm{~N}$ $\mathrm{NaOH}$ and phenolphthalein as an indicator. The results were expressed in $\mathrm{g}$ citric acid/100 $\mathrm{g}$ of fresh weight (AOAC, 2012). The TSS/TTA ratio was calculated from the quotient between the concentration of total soluble solids and total

titratable acidity.

Instrumental color was evaluated using a colorimeter (KONICA MINOLTA), CR 410 model, measuring three different points on the surface of $L$. canadensis and $A$. cordifolia leaves. The parameter $\mathrm{L}$ corresponds to lightness, which indicates how light the sample is, with values ranging from 0 (totally black) to 100 (totally white). The coordinate $a^{*}$ corresponds to the red and green extremes, whereas the coordinate $b^{*}$ is related to the intensity from blue to yellow.

\section{Natural antioxidants}

The content of carotenoids was evaluated by spectrophotometry, by initially extracting the analyte in acetone (A.R.) and subsequently separating it by a partition with petroleum ether (A.R.). After separation of phases, the aqueous phase was discarded and the ethereal, after final adjustment of volume, was subjected to absorbance reading in a spectrophotometer (FEMTO LTDA) at $450 \mathrm{~nm}$ wavelength. The content of carotenoids was calculated by Equation 1, and the results were expressed in $\mathrm{mg}$ of total carotenoids/100 $\mathrm{g}$ of sample, according to the methodology described by RodriguezAmaya (2001).

(Eq. 1) $\mathrm{TC}=100\left[\left(\mathrm{~A} \times \mathrm{V} \times 10^{\wedge} 4\right) /(\mathrm{E} 1 \% 1 \mathrm{~cm} \times \mathrm{M})\right]$ Where: $A=$ Absorbance at $450 \mathrm{~nm}$, multiplied by the dilution factor; $V=$ Sample volume $(25 \mathrm{~mL})$; $\mathrm{E} 1 \% 1 \mathrm{~cm}=$ Extinction coefficient of betacarotene in petroleum ether $=2592 ; \mathrm{M}=$ Sample mass (2 $\mathrm{g})$.

The content of tannins was determined using the vanillin/HCl method (PRICE et al., 1978), in which $2.0 \mathrm{~g}$ of vegetables previously macerated were mixed with acidified methanol $(1 \% \mathrm{HCl})$. The samples were shaken in vortex mixer (ARSEC, TS200), centrifuged (3000 rpm) for $15 \mathrm{~min}$, kept at $30{ }^{\circ} \mathrm{C}$ for $20 \mathrm{~min}$ in a water bath (MARCONI,
MA18416) and then mixed with vanillin/ $\mathrm{HCl}$ solution. Absorbance was read at $500 \mathrm{~nm}$ in a FEMTO spectrophotometer (700S). Tannin concentrations in the samples were determined by constructing a standard curve obtained from different catechin concentrations. Tannin contents were calculated using Equation 2.

(Eq. 2) $\mathrm{T}=(\mathrm{A}-\mathrm{B}) \times 8 /$ (Ca $\times$ sample weight)

Where: $\mathrm{A}=$ Sample absorbance; $\mathrm{B}=$ Sample blank; $\mathrm{Ca}=$ Angular coefficient of the standard curve.

The content of total phenolic compounds was determined by the Folin-Ciocalteau method, and calculations were made based on a calibration curve constructed using gallic acid. Absorbance was read in a FEMTO spectrophotometer (700S) at $740 \mathrm{~nm}$ and the results were expressed in $\mathrm{mg}$ of gallic acid equivalent (GAE) per $100 \mathrm{~g}$ of dry sample (SINGLETON et al., 1999).

The experiment was conducted in a completely randomized design (CRD) with three replications, data collected in triplicate were subjected to a variance analysis with one factor (one-way ANOVA), after verifying the assumptions of normality and homogeneity through Shapiro-Wilk and Levene tests and subsequent or Tukey test applied for media comparison of qualitative factors, use of free software SPSS version 15.0 pt., with $5 \%$ probability $(p \leq 0.05)$. Whereas those of quantitative factors were analyzed by regression $(p<0.05)$, through the statistical program $\mathrm{R}$ Core Team (2017).

\section{Results and Discussion \\ Physical-chemical analyses}

It was observed for both studied species, Lactuca canadensis (Figures 2A, 2C and 2E) and Anredera cordifolia (Figures 2B, 2D and 2F), a linear adjustment for the characteristics SST ( ${ }^{\circ}$ Brix), ratio SST/TTA (Total Titratable Acidity TTA, $g$ citric acid/100 g of fresh weight) and $\mathrm{pH}$ in that as the storage time increased the values of these characteristics also increased. 
Figure 2. Physical-chemical characteristics: total soluble solids (TSS, $\left.{ }^{\circ} \mathrm{BRIX}\right)$, hydrogen potential $(\mathrm{pH})$ and ratio SST ( ${ }^{\circ}$ Brix )/(Total Titratable Acidity -TTA, g citric acid/100 g of fresh weight).
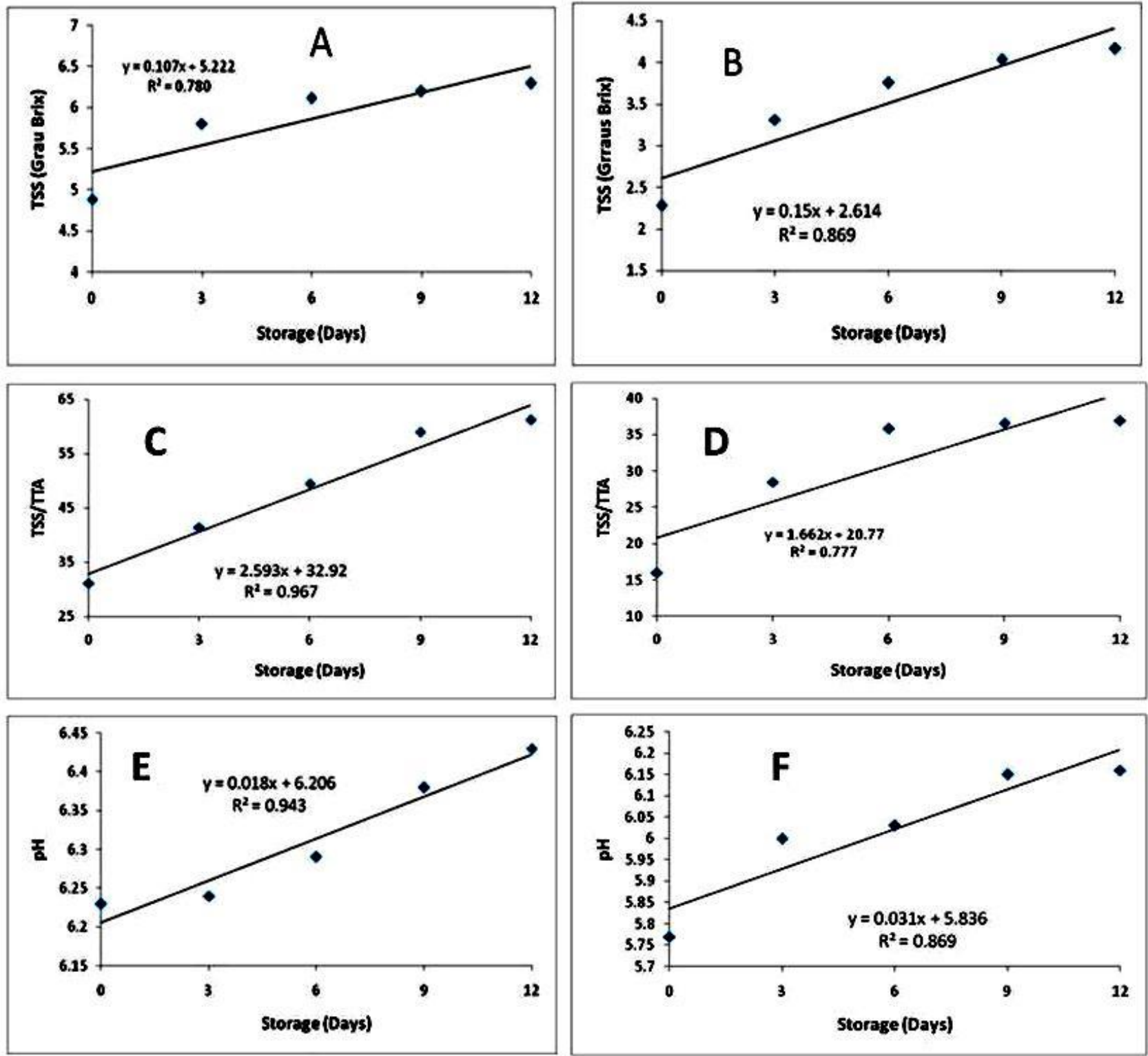

The contents of total soluble solids increased over the storage period in both $A$. cordifolia and L. canadensis, ranging from 2.28 to $4.17^{\circ}$ Brix and from 4.89 to $6.30{ }^{\circ}$ Brix, respectively. These results corroborate those reported by Sanches et al. (2017), who also observed oscillations in the contents of soluble solids in different minimally processed genotypes of lettuce, over 12 days of storage, with an increase from the 9th day in some cultivars.

According to Moraes et al. (2008), increment in the concentration of solids can be explained by the loss of moisture in the vegetable, due to the minimal processing, and during storage. This parameter is extremely important for the acceptance of the vegetables by the consumers since the presence of carbohydrates and consequently the sweetness are important characteristics in their choice decision (MENEZES et al., 2009).

Regarding to the TSS/TTA ratio, according to Amorim et al. (2010), the higher the values, the better the taste, due to the balance between acidity and sweetness. For the evaluated samples, there was no significant difference from the 3rd to the 9th day ( $p>0.05)$

The values of $\mathrm{pH}$ varied between 5.77 and 6.16 in A. cordifolia. In addition, until the 6th day of evaluation, this vegetable showed characteristics similar to those observed at the time zero (T0). From days 3 to 12 , no significant variation was observed ( $p>0.05)$. In L. canadensis, $\mathrm{pH}$ values ranged from 6.23 to 6.43 along the analyzed period. 
Menezes et al. (2005) observed that $\mathrm{pH}$ of minimally processed smooth lettuce (Lactuca sativa) stored at $5^{\circ} \mathrm{C}$ varied from 5.80 to 6.40 , similar values to the ones found in this work. Additionally, Shances et al. (2017) observed that minimally processed lettuce cultivars $\mathrm{pH}$ increased in twelve days of storage.

For the moisture characteristic, there was no significant effect of storage time for the species
A. cordifolia and the values varied from $90.21 \%$ to $91.45 \%$ ( $p>0.05)$. For the specie L. canadensis, a linear decrease was observed with the storage time (Figure 3). These values demonstrate that water was the major component in these minimally processed vegetables.

Figure 3. Moisture characteristic in function of days of storage for the species Lactuca canadensis.

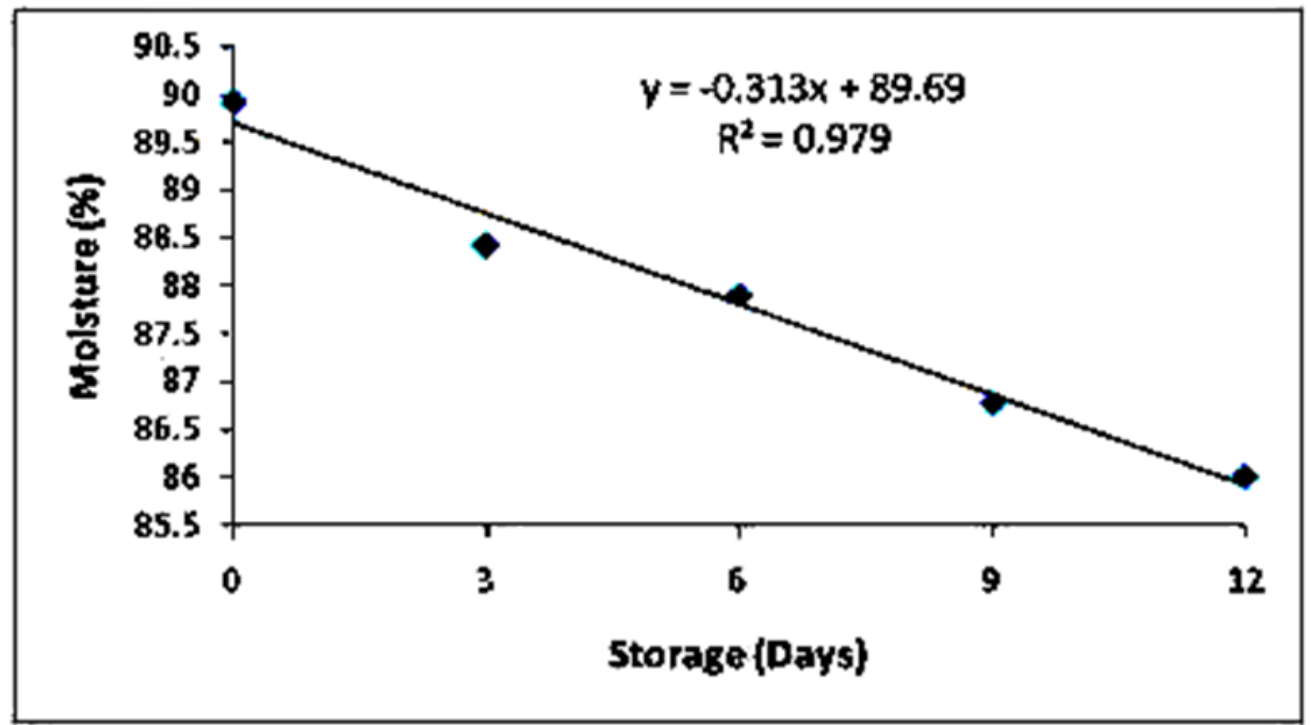

Concerning the total titratable acidity values, there was no significant influence along the evaluated period in any of the samples ( $p>0.05$ ), demonstrating that this characteristic, which is an important physical-chemical parameter, did not change along the 12 days of storage at 7 o C. Corroborating these results, Viana et al. (2015) observed TTA of $0.11 \mathrm{~g}$ citric acid/100 g of fresh weight in A. cordifolia leaves.

Ferreira et al. (2014) also observed no alteration of acidity in minimally processed white cabbage, 14 days of storage under refrigeration. With a few exceptions, the vegetables showed low acidity, which makes them susceptible to bacterial and fungal contamination, suggesting that one of the parameters of food preservation is acidity.

In terms of color, when evaluating $L$. canadensis, there was no statistical difference between storage times ( $p>0.05)$, with $L^{*}$ values found in the range (47.71 to 51.81), a* (-15.92 to -13.71) and $b^{*}$ (18.65 to 20.22). Only the lightness $\left(L^{*}\right)$ parameter of $A$. cordifolia differed statistically between the times, ranging from 36.71 to $33.36(p<0.05)$. The lightness of the product could be maintained until the $6^{\text {th }}$ day of storage, compared to the first day of storage, with values for $\left(a^{*}\right)$ ranging from $-15,24$ to $-13,18$ and $\left(b^{*}\right) 18,30$ to 20,83 .

According to Moura et al. (2016), the change in appearance, usually darkening, is the alteration that most occurs in fruits and vegetables during prolonged storage. This undesirable characteristic is accelerated by the mechanical rupture of cells, caused by the action of cutting, which intensifies the enzymatic activity.

Since the leaves of the vegetables were not cut in the present study, their color parameters showed no expressive variation, being preserved along the entire storage time, which demonstrates that minimal processing (keeping the leaves whole) proves to be a beneficial option, especially for not significantly affecting the green color intensity of the products during the 12 days.

\section{Natural antioxidants}

The contents of total carotenoids varied from 39.54 to $23.33 \mu \mathrm{g} / 100 \mathrm{~g}$ in L. canadensis and from 
25.94 to $15.00 \mu \mathrm{g} / 100 \mathrm{~g}$ in $A$. cordifolia, along the 12-day storage at $7 \stackrel{\circ}{\circ} \mathrm{C}$ (Figure 4).

Figure 4. Contents of Carotenoids in function of days of storage.

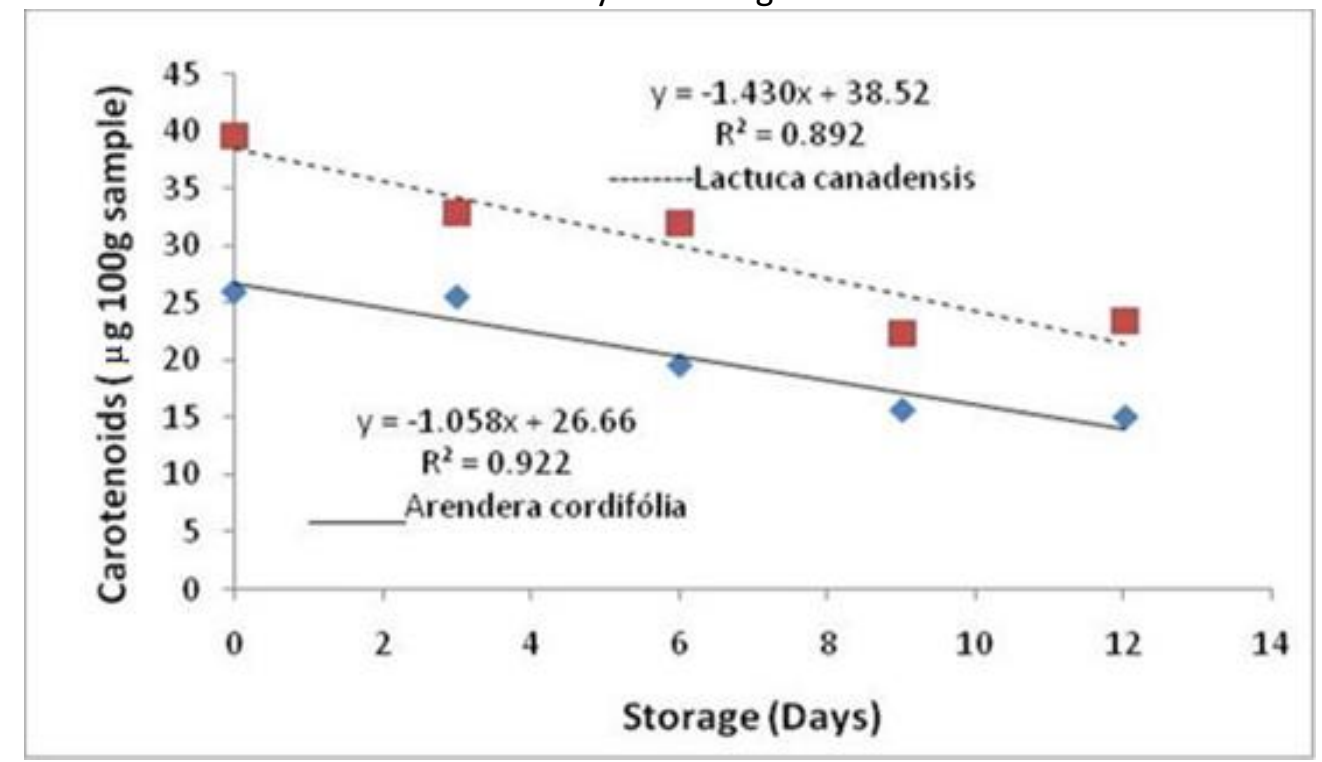

There was a linear effect where the increase in storage time decreased the content of carotenoids. In absolute values, the species Lactuca canadensis presented higher contents than Anredera cordifolia. However, this difference is probably due to the genotype. Considering the end of the storage period, the contents of carotenoids in both $L$. canadensis and A. cordifolia showed important retentions (59.00\% and $57.8 \%$, respectively).

Evaluating the composition of carotenoids present in minimally processed leafy vegetables (Lactuca sativa var. romana), stored in packed clear polymer retail boxes for twelve days at $4 \stackrel{\circ}{ } \mathrm{C}$, Saini et al. (2016) observed losses of 7,55\%, $13,29 \%, 12,67 \%$ and $7,45 \%$ in All-E-violaxanthin, 9 '-Z-neoxanthin, All-E-lutein and total carotenoids, respectively.

Carotenoids are pigments widely spread in nature and arouse interest due to their preventive action in different types of disease, such as delay in cataract development (NWACHUKWU et al., 2016), increase in bone mineral density (CHEN et al., 2015) and prevention of heart diseases (CSEPANYI et al.,
2015). As an example, we have $\beta$-carotene, which is a precursor of vitamin $A$, this activity occurs after its conversion into retinol (RE) inside the body, the molecule being cleaved by a specific intestinal enzyme, into two vitamin molecules (UENOJO et al., 2007).

According to RDC $n^{\circ} 269$ of September 2005, the amount of vitamin $A$ that should be consumed daily to meet the needs of most individuals and groups of people in a healthy adult population is $600 \mu \mathrm{g} \mathrm{RE}$, these being equivalent to $3.59 \mathrm{mg} \beta$-carotene and $7.14 \mathrm{mg}$ of other pro vitamin carotenoids (BRASIL, 2005).

During the storage period, while $L$. canadensis leaves showed a variation of 1.02 to $0.67 \mathrm{mg}$ $\mathrm{CE} / \mathrm{g}$, tannin concentrations in $A$. cordifolia leaves ranged from 0.33 to $0.21 \mathrm{mg} \mathrm{CE} / \mathrm{g}$ (Figure 5). The retention of these compounds after 12 days of storage was approximately $66.13 \%$ in $L$. canadensis and $62.86 \%$ in A. cordifolia. Corroborating these results, Viana et al. (2015) found tannin contents around $0.33 \mathrm{mg} \mathrm{CE} / \mathrm{g}$ in $A$. cordifolia leaves. 
Figure 5. Contents of tannins in function of days of storage.

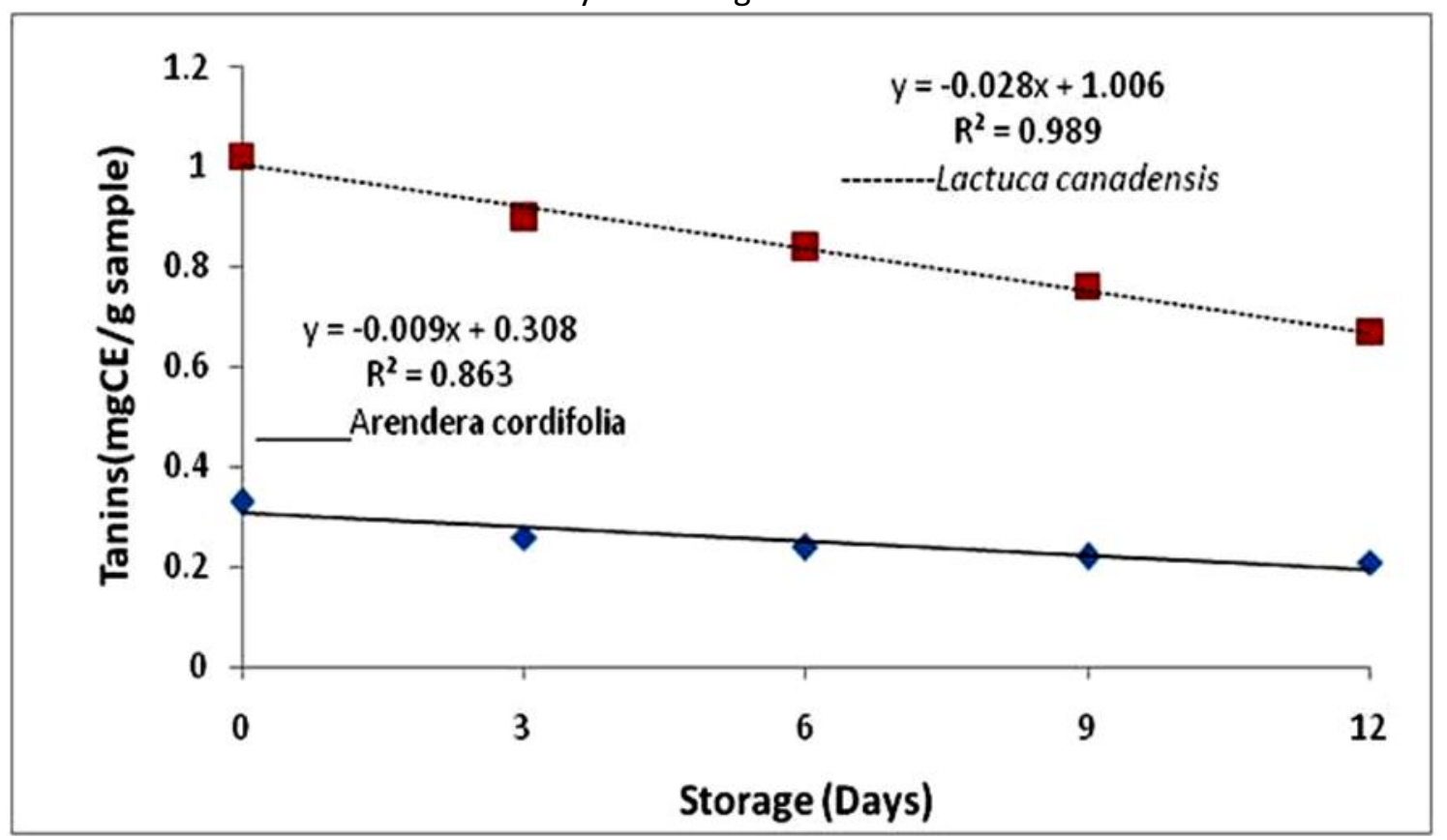

There was a linear effect where the measurement of the increase in storage time decreased the content of tannins. In absolute values, the species $L$. canadensis presented higher contents than A. cordifolia. However, this difference is probably due to the genotype.

Historically, tannins have been considered undesirable from the sensory point of view, due to their astringency, and from the nutritional point of view, due to the reduction in the availability of certain macromolecules, such as carbohydrates (YANG et al., 2009). However, studies have already demonstrated the positive effects of these compounds, which have great potential in the control of diabetes and obesity in humans (YANG et al., 2009).

In India, the average intake of tannins by the population ranges from 1.5 to $2.5 \mathrm{~g} /$ day, while North American consumption is in the range of 1 g/day. A daily intake of catechin and proanthocyanidin dimers and trimers estimated between 18 and $50 \mathrm{mg} / \mathrm{d}$, with the main sources being grapes, red wine, chocolate, tea, apples, pears (KUMARI; JAIN et al., 2012).

In general, it is known that these compounds are important in the diet of diabetic patients, since they can reduce the activity of the enzyme $\alpha$-amylase, which digests or amide, resulting in the lowest glycemic response (ANUNCIAÇÃO et al., 2018). Tannins are also bioactive compounds capable of helping in healing processes of inflammations, acting as protein-complexing agents on the injured epithelial tissues (NAGULSAMY et al., 2015).

In this context, the importance of products containing this substance and studies on them are intensified, because research aiming to evaluate these polyphenols in edible plants is scarce.

The contents of total phenolic compounds found in minimally processed $L$. canadensis varied from 97.16 to $79.75 \mathrm{mg} \mathrm{GAE} / 100 \mathrm{~g}$, with a loss of $17.92 \%$ along the evaluation period (Figure 6). 
Figure 6. Contents of phenolic compounds in function of days of storage.

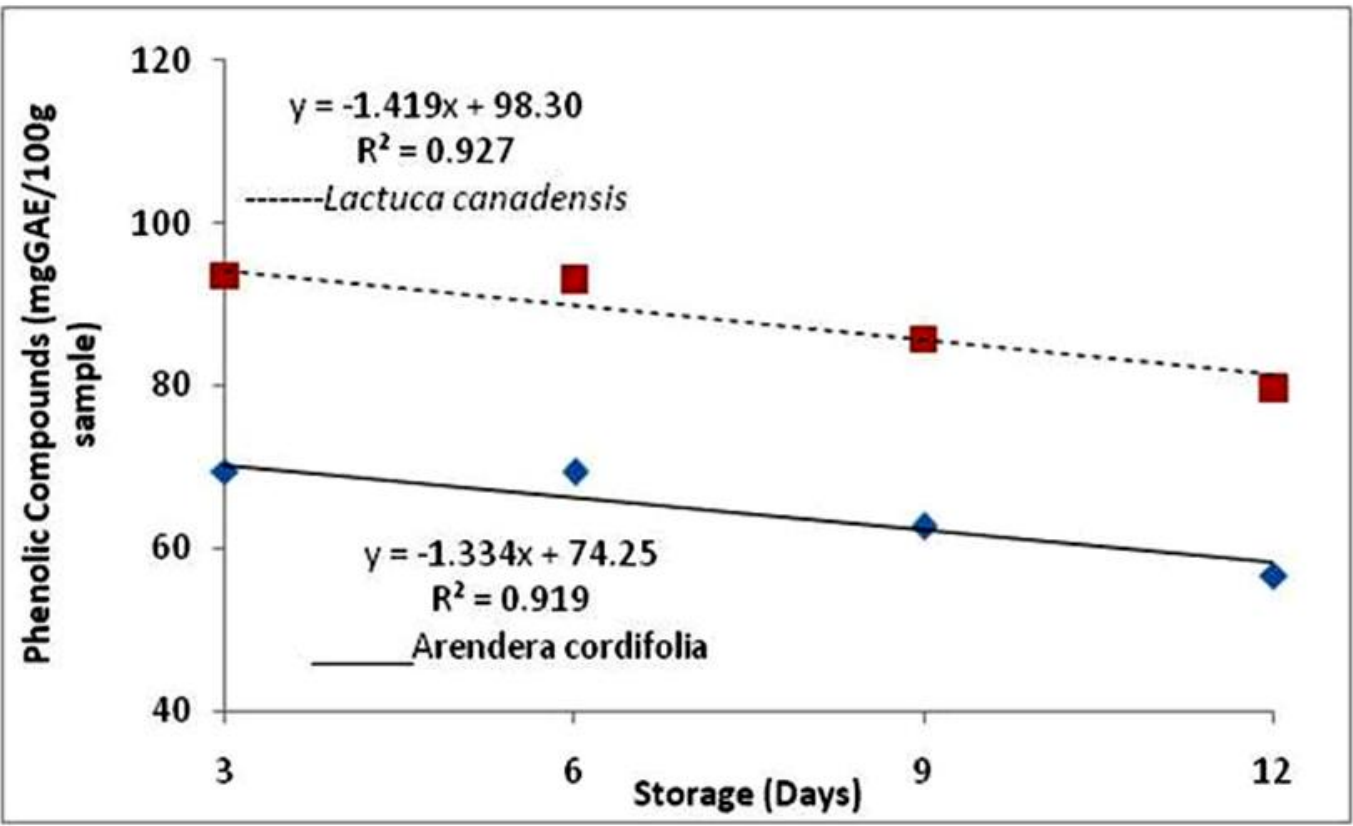

There was a linear effect where the measurement of the increase in storage time decreased the content of phenolic compounds. In absolute values, the species $L$. canadensis presented higher contents than $A$. cordifolia. However, this difference is probably due to the genotype.

The presence and preservation of these phytochemicals in vegetables are very important because they have a significant antioxidant effect, ensuring microbiological stability in foods and inhibitory potential against free radicals (HASSIMOTTO et al., 2005). Based on the retention percentage $(82.08 \%)$, it is worth pointing out that minimal processing is an advantageous option for this vegetable.

Arbos et al. (2010), evaluating the contents of phenolic compounds in organic and conventional Cichorium intybus L. (chicory grown), observed concentrations of 92.15 and $81.04 \mathrm{mg} \mathrm{GAE} / 100 \mathrm{~g}$ in the studied products, respectively. These values are within the range found in the present study, which aimed to evaluate the influence of storage time.

In $A$. cordifolia, the contents of antioxidant compounds varied from 73.20 to $56.53 \mathrm{mg}$ $\mathrm{GAE} / 100 \mathrm{~g}$, showing retention of $77.22 \%$. These values are higher than those reported by Viana et al. (2015), who evaluated $A$. cordifolia plants and found total phenolic compound content of $25 \mathrm{mg}$ GAE/100g.

The effect of minimal processing and subsequent storage under refrigeration on the contents of total phenolic compounds in Swiss chard and American lettuce was studied by Carnelossi et al. (2012), and these authors found that the concentration of these phytochemicals decreased by $20 \%$ along 15 days of storage for chard.

The instability in the concentration of antioxidant compounds in the minimally processed plants evaluated can be explained by the fact that, in fruits and vegetables, the content of total phenolic compounds is strongly influenced by genetic factors, storage, environmental conditions, degree of maturity and plant variety, mechanical injuries, besides the type of cultivation (NACZK; SHAHIDI, 2006).

Therefore, the results of the present study demonstrate that the minimally processed nonconventional vegetables evaluated showed physical-chemical and antioxidant potential and that their storage influenced the contents of these bioactive compounds. However, the retention percentage of these phytochemicals remained expressive, indicating an advantage in conducting this process.

Based on physical-chemical and functional aspects, these plants can be consumed until the twelfth day of storage, because good retention of antioxidant compounds were observed during this period.

\section{Conclusions}

The green color and total titratable acidity of the studied vegetables remained within a similar 
range of values along the entire period of storage. Variations of $\mathrm{pH}$ and total soluble solids had no negative influence along the 12 days of evaluation. During the analyzed period, storage affected the concentrations of natural antioxidants in the minimally processed vegetables, but the retention of these compounds was still expressive, demonstrating the viability of conducting these processes.

These products can be consumed until the $12^{\text {th }}$ day of storage, because of the satisfactory physical-chemical characteristics and stability of antioxidant compounds detected. This is worth pointing out the pioneering nature of the present study with these non-conventional vegetables.

\section{References}

ASSOCIATION OF OFFICIAL ANALYTICAL CHEMISTRY (AOAC). Official methods of analysis of the Association of Official Analytical Chemistry. 19. ed. Gaithersburg: AOAC, 2012.

AMORIM, G. M.; SANTOS, T. C.; PACHECO, C. S. V.; TAVARES, I. M. C.; FRANCO, M. Physicalchemical, microbiological and sensory evaluation of fruit pulp sold in Itapetinga-BA. Enciclopédia Biosfera, v. 6, p. 1-8, 2010.

ANUNCIAÇÃO, P. C.; CARDOSO, L. M.; QUEIROZ, V. A. V.; MENEZES, C. B.; CARVALHO, C. W. P.; PINHEIRO-SANT'ANA, H. M.; ALFENAS, R. C. G. Consumption of a drink containing extruded sorghum reduces glycaemic response of the subsequent meal. European Journal of Nutrition, v. 57, p. 251-257, 2018.

https://doi.org/10.1007/s00394-016-1314-x

ARBOS, K. A.; FREITAS, R. J. S.; STERRZ, S. C.; DORNAS, M. F. Antioxidant activity and phenolic content in organic and conventional vegetables. Ciência Tecnologia de Alimentos, v. 30, p. 501506, 2010. http://dx.doi.org/10.1590/S010120612010000200031.

BRASIL. Agência Nacional de Vigilância Sanitária. Resolução no 269/2005, de 22 de setembro de 2005. Regulamento técnico sobre a ingestão diária recomendada (IDR) de proteína, vitaminas e minerais. Brasília: ANVISA, 2005.

BRASIL. Ministério da Agricultura, Pecuária e Abastecimento. Secretaria de Desenvolvimento Agropecuário e Cooperativismo. Manual de hortaliças não-convencionais. Brasília: Mapa/ACS, 2010. 92 p.

BRESSAN, R. A.; REDDY, M. P.; CHUNG, S. H.; YUN, D. J.; HARDIN, L. S.; BOHNERT H. J. Stress-adapted extremophiles provide energy without interference with food production. Food Security, v. 3, p. 93-105, 2011.

https://doi.org/10.1007/s12571-011-0112-9.

CARNELOSSI, M. A. G.; SOUZA, J. F.; SOARES, L. S.; FURTADO, M. C.; REIS, I. A. O.; REBOUÇAS, K. H.; SANTOS, R. M.; CASTRO, A. A. Conservation of Minimally Processed Swiss Chard, American Lettuce and Purple Lettuce in Different Packaging Alone and as Mixed Salad. Acta Horticulturae, v. 934, p. 649-656, 2012.

https://doi.org/10.17660/ActaHortic.2012.934.86

CHEN, G.; ZHU, Y.-Y.; CAO, Y.; LIU, J.; SHI, W.; LIU, Z.; CHEN, Y. Association of dietary consumption and serum levels of vitamin $A$ and $\beta$-carotene with bone mineral density in Chinese adults. Bone, v. 79, p. 110-115, 2015.

https://doi.org/10.1016/j.bone.2015.05.028

CSEPANYI, E.; CZOMPA, A.; HAINES, D.; LEKLI, I.; BAKONDI, E.; BALLA, G.; TOSAKI, A.; BAK, I. Cardiovascular effects of low versus high-dose beta-carotene in a rat model. Pharmacological Research, v. 100, p. 148-156, 2015.

https://doi.org/10.1016/i.phrs.2015.07.021

EMPRESA DE PESQUISA AGROPECUÁRIA DE MINAS GERAIS (EPAMIG). Hortaliças não convencionais. Minas Gerais: EPAMIG, 2012. Available at:

http://www.epamig.br/index.php?option= comdocman\&task=doc_download\&gid=1734.

Accessed on: Apr. 062019.

FERREIRA, T. A.; SILVA, C. O; PASCOAL, G. B. Physical and chemical analysis in minimally processed white cabbage (Brassica oleracea) during the conditioning under refrigeration. Linkania, v. 1, p. 59-72, 2014.

GRANATO, D.; ALEZANDRO, M. R.; NAZZARO, F. Food bioactive compounds: quality control and bioactivity. Food Research International, v. 77, n. 2, p. 73-74, 2015. https://doi.org/10.1016/j.foodres.2015.10.011 
HASSIMOTTO, N. M. A.; GENOVESE, M. I.; LAJOLO, F. M. Antioxidant activity of dietary fruits, vegetables, and commercial frozen fruit pulps. Journal of Agriculture and Food Chemistry, v. 53, p. 2928-2935, 2005.

https://doi.org/10.1021/jf047894h

KINUPP, V. F.; LORENZI, H. Plantas alimentícias não-convencionais (PANCs) no Brasil: guia de identificação, aspectos nutricionais e receitas ilustradas. São Paulo: Plantarum, 2014. 768 p.

KUMARI, M.; JAIN, S. Tannins: an antinutrient with positive effect to manage diabetes. Research Journal of Recent Sciences, v. 1, p. 7073, 2012.

MACHADO, C. C.; BOSCOLO, O. H. Plantas alimentícias não convencionais em quintais da comunidade da Fazendinha, Niterói, Rio de Janeiro, Brasil. Revista Brasileira de Biociências, v. 16, n.1, p. 28-26, 2018.

http://www.ufrgs.br/seerbio/ojs/index.php/rbb/ article/view/4031

MENEZES, E. M. S., FERNANDES, É. C.; SABAASRUR, U. Folhas de alface lisa (Lactuca sativa) minimamente processadas armazenadas em atmosfera modificada: análises físicas, químicas e físico-químicas. Ciência e Tecnologia de Alimentos, v. 25, n. 1, p. 60-62, 2005.

https://doi.org/10.1590/S0101$\underline{20612005000100010}$

MENEZES, C. C.; BORGES, S. V.; CIRILLO, M. A.; FERRUA, F. Q.; OLIVEIRA, L. F.; MESQUITA, K. S. Physical and physicochemical characterisation of different formulations of guava preserve (Psidium guajava L.) from Pedro Sato cultivar. Ciência e Tecnologia de Alimentos, v. 29, n. 3, p. 618-625, $2009 . \quad$ https://doi.org/10.1590/S0101$\underline{20612009000300025}$

MORAES, I. V. M.; CENCI, S. A.; BENEDETTI, B. C.; MAMEDE, A. M. G. N.; SOARES, A. G.; BARBOZA, H. T. G. Physical and chemical characteristics of minimally processed strawberries stored under refrigeration and controled atmospheres. Ciência e Tecnologia de Alimentos, v. 28, p. 274-281, $2008 . \quad$ http://dx.doi.org/10.1590/S0101$\underline{20612008000200003}$

MOURA, L. O.; CARLOS, L. A.; OLIVEIRA, K. G.; MARTINS, L. M.; DA SILVA, E. C. Physicochemical characteristics of purple Lettuce harvested at different ages. Revista Caatinga, v. 29, n. 2, p. 489-495, 2016. https://doi.org/10.1590/1983$\underline{21252016 v 29 n 227 r c}$

NACZK, M.; SHAHIDI, F. Phenolics in cereals, fruits ang vegetables: occurence, extraction and analysis. Journal of Pharmaceutical and Biomedical Analysis, v. 41, n. 5, p. 1523-1542, 2006. https://doi.org/10.1016/j.jpba.2006.04.002

NAGULSAMY, P.; PONNUSAMY, R.; THANGARAJ, $P$. Evaluation of antioxidant, anti-inflammatory, and antiulcer properties of Vaccinium leschenaultii Wight: A therapeutic supplement. Journal of Food and Drug analysis, v. 23, n. 3, p. 376-386, 2015.

https://doi.org/10.1016/i.jfda.2014.11.003

NWACHUKWU, I. D.; UDENIGWE, C. C.; ALUKO, R. E. Lutein and zeaxanthin: production technology, bioavailability, mechanisms of action, visual function and health claim status. Trends in Food Science and Technology, v. 49, p. 74-84, 2016. https://doi.org/10.1016/j.tifs.2015.12.005

PRICE, M. L.; VAN SCOYO, S.; BUTLER, L. G. A critical evaluation of the vanillin reaction as an assay for tannin in sorghum grain. Journal of Agricultural and Food Chemistry, v. 26, n. 5, p. 1214-1218, 1978.

https://doi.org/10.1021/if60219a031

QUEIROZ, C. R. A. A.; FERREIRA, L.; GOMES, L. B. P.; MELO, C. M .T.; ANDADRE, R. R. Ora-pro-nóbis in human food consumption: sensorial perception. Revista Verde de Agroecologia e Desenvolvimento Sustentável, v. 10, n. 3, p. 0105, 2015.

https://doi.org/10.18378/rvads.v10i3.3393

RICO, D.; MATÍN-DIANA, A. B.; BARAT, J. M.; BARRY-RYAN, C. Extending and measuring the quality of fresh-cut fruit and vegetables: a review. Trends in Food Science \& Technology, v. 18, n. 7, p. 373-386, 2007.

https://doi.org/10.1016/j.tifs.2007.03.011

RODRIGUEZ-AMAYA, D. B. A. Guide to carotenoid analysis in foods. Washington: OMNI Research, 2001. 64 p.

SAINI, R. K.; SHANG, X. M.; KO, E. Y.; CHOI, J. H.; KIM, D.; KEUM, Y. S. Stability of carotenoids and 
tocopherols in ready-to-eat baby-leaf lettuce and salad rocket during low-temperature storage. International Journal of Food Sciences and Nutrition, v. 67, n. 5, p. 489-495, 2016. http://dx.doi.org/10.3109/09637486.2016.11720 $\underline{59}$

SANCHES, A. G.; SILVA, M. B. da; MOREIRA, E. G. S.; COSTA, J. M.; COSME, S. S.; CORDEIRO, C. A. M. Avaliação da qualidade de alfaces minimamente processadas cultivadas em sistema hidropônico. Revista Trópica: Ciências Agrárias e Biológicas, v. 9, n. 1, p. 19-31, 2017.

SANTOS, J.; HERRERO, M.; MENDIOLA, J. A.; OLIVEIRA-TELES, M. T.; IBÁÑES, E.; DELERUEMATOS, C.; OLIVEIRA, M. B. P. P. Fresh-cut aromatic herbs: nutritional quality stability during shelf life. Food Science and Technology, v. 59, n. 1, p. 101-107, 2014.

https://doi.org/10.1016/i.lwt.2014.05.019

SINGLETON, V. L.; ORTHOPER, R.; LAMUELARAVENTÓS, R. M. Analysis of total phenols and other oxidation substrates and antioxidants by means of Folin-Ciocalteu reagent. Methods in Enzymology, v. 299, p. 152-179, 1999. https://doi.org/10.1016/S0076-6879(99)99017-1

TOSHIYUKI, M.; KAZUHIRO, H.; MASAYUKI, Y. Structures of new oleanane- type triterpene oligoglycosides, basella saponins $A, B, C$, and D, from the fresh aerial parts of Basella rubra $\mathrm{L}$. Chemical Pharm Bull, v. 49, p. 776-779, 2001.

https://doi.org/10.1248/cpb.49.776

UENOJO, M.; JÚNIOR, M. R. M.; PASTORE, G. M. Carotenoides: propriedades, aplicações e biotransformação para formação de compostos de aroma. Química Nova, v. 30, n. 3, p. 616-622, $2007 . \quad$ https://doi.org/10.1590/S010040422007000300022

VIANA, M. M. S.; CARLOS, L. A.; SILVA, E. C.; PEREIRA, S. M. F.; OLIVEIRA, D. B.; ASSIS, M. L. V. Phytochemical composition and antioxidant potential of unconventional vegetables. Horticultura Brasileira, v. 33, n. 4, p. 504-509, $2015 . \quad$ http://dx.doi.org/10.1590/S0102$\underline{053620150000400016}$

YANG, L.; BROWNING, J. D.; AWIKA, J. M. Sorghum 3-Deoxyanthocyanins Possess Strong Phase II Enzyme Inducer Activity and Cancer Cell
Growth Inhibition Properties, Journal of Agricultural and Food Chemistry, v. 57, n. 5, p. 1797-1804, 2009.

https://doi.org/10.1021/jf8035066

YEN, G. C.; CHEN, H. Y; PENG H. H. Evaluation of the cytotoxicity, mutagenicity and antimutagenicity of emerging edible plants. Food and Chemical Toxicology, v. 39, n. 11, p. 1045 1053, 2001. https://doi.org/10.1016/s02786915(01)00053-9 